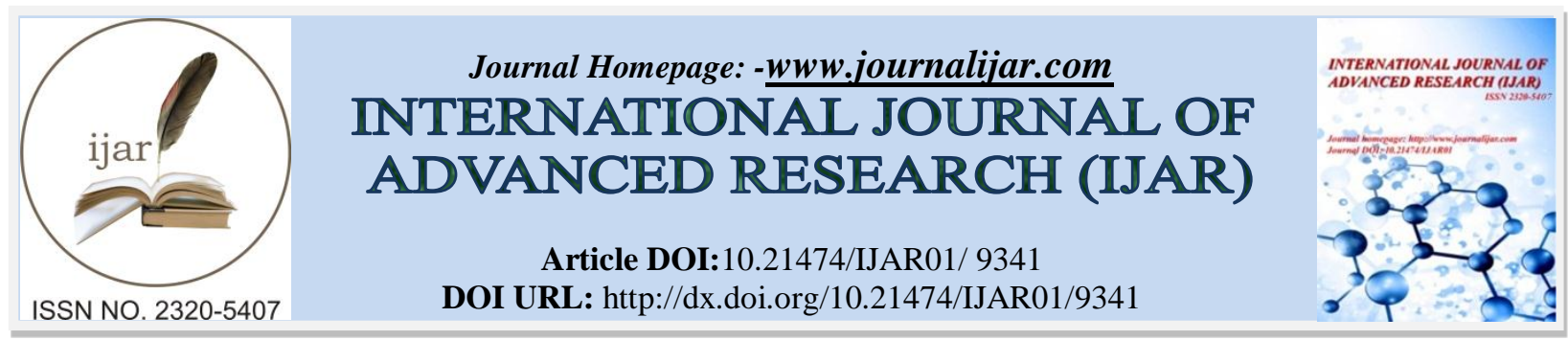

RESEARCH ARTICLE

\title{
LITRARY REVIEW OF YUVAN PIDIKA.
}

Dr. Awadhesh kumar ${ }^{1}$, Dr. Bhoopal Shashidhar ${ }^{2}$ and Dr. Pankaj Kumar Rajvanshi ${ }^{3}$.

1. Assistant Professor Department of Rachana Sharir, Major S. D. Singh PG Ayurvedic Medical College and Hospital, Fatehgarh- Farrukhabad, Uttar Pradesh.

2. Associate Professor department of Rachana Sharir, Himalayiya Ayurvedic PG medical college and Hospital Dehradun Uttarakhand.

3. Assistant Professor department of Rachana Sharir, Himalayiya Ayurvedic PG medical college and Hospital Dehradun Uttarakhand.

\section{Manuscript Info}

Manuscript History

Received: 04 May 2019

Final Accepted: 06 June 2019

Published: July 2019

Key words:-

Twaka, Yuvan pidika, Skin, Sharir.

\section{Abstract}

Most of the diseases which are exclusively exhibited on the skin are termed as kushta roga in ayurveda. Yuvanpidika is a most common anomaly; it is not described in major diseases in kushta but described elsewhere in kshudra kushta usually self limiting. Found in teenagers and young adults. Yuvan pidika is resembles like 'Salmali Kantaka' on the face of a young men or women is called yuva Anana and its pidika is Yuvan Pidika.

Copy Right, IJAR, 2019,. All rights reserved.

\section{Introduction:-}

The brief description available for the disease 'Yuvan pidika' all the classics have mentioned kapha, vata, rakta as the causative factors of the disease while Bhavapraksha mentioned swabhava as the cause of the disease. In Sarangdhara Samhita, Vaktra snigdhata and pidika have been mentioned which are produced due to shukradhatu mala. So it may be concluded that the swabhava of the particular age, excess production of shukra dhatu and its mala along with the imbalanced state of doshas is the cause of the disease. In this condition the main doshas involved are vata, kapha dosha and rakta.

\section{Vyutpatti Of Yuvan Pidika-}

1. Youvanam (yuno bhav: an $)^{1}$

2. The meaning of youvana is tarunya (young)

3. The word Pindika is made by- pind+ nwul + itwam means round swelling ${ }^{2}$

4. So by these two vyotpaties, yuvan pidika is a circular swelling or eruption i.e. papule, pustule, nodule etc that develops on the face.

The word 'Yuvan pidika' consist of two terms these are Yuvan and Pidika.

\section{Yuvan:}

1. The word yuvan is derived from the root 'Yu Dhatu' by using 'Kanin pratyaya'.

2. Here yuvan term is used in the sense of young or adult ${ }^{3}$.

3. According to shabdakalpadruma youvvana is considered as the age period. Yuvan started from the age of sixteen and after seventy years person is considered to be vruddha. 


\section{Pidika:}

1. This word is derived from the root of 'Peed Dhatu' by using "Dvul+Tap pratyaya" with it"

2. Peed dhatu suggests the sense of pain so, the meaning of pidaka is painful eruption.

\section{Nirukti-}

1. Yuvan pidika is resembles like 'Salmali Kantaka' on the face of a young men or women is called yuva Anana and its pidika is Yuvan Pidika'.

2. Yuvan pidika vigraha - $\operatorname{Yuv}(n)+\operatorname{An}(n)+$ Pidaka $^{6}$.

Looking into all the above derivations, Yuvan pidika can be taken as a rounded swelling which occurs in the young adults presenting with pain and paka as symptoms.

\section{Synonyms of the yuvan padika:}

1. Yuvan Padika

2. Mukhadusika ${ }^{7}$

3. Anana dusika

4. Vayasphoda

5. Tarunya Pidika

6. Yuvaganda

7. Youvan Kantaka ${ }^{8}$

8. kshudra Sphotaka

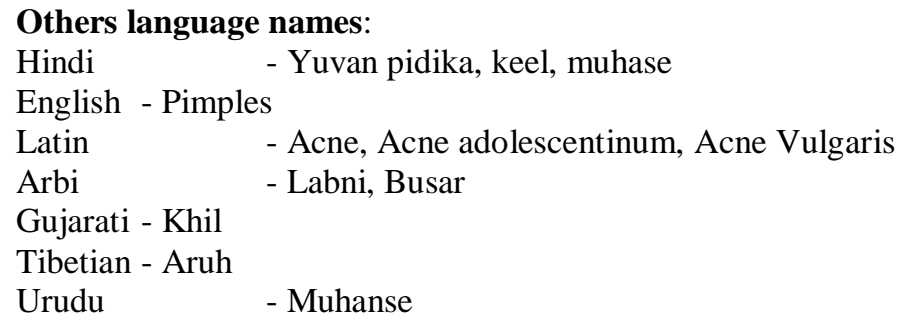

\section{Nidana:}

1. In the brief description available for the disease 'Yuvan pidika' all the samhitas have mentioned kapha, vata, rakta as the causative factors of the disease while Bhavapraksha mentioned swabhava as the cause of the disease ${ }^{9}$.

2. In sarangdhara samhita, Vaktra snigdhata and pidaka have been mentioned which are produced due to shukradhatu mala ${ }^{10}$.

3. So it may be concluded that the swabhava of the particular age, excess production of shukra dhatu and its mala along with the imbalanced state of doshas is the cause of the disease.

4. In this condition the main doshas involved are vata, kapha dosha and rakta. So nidanas which vitiate the same are considered here.

\section{Kapha prakopaka hetu:}

Aharajanya :

Gurudravya Sevana, Madhura, Snigdha, Pichilla, Abhishyandi Dravya Sevana Dugdha, Dadhi, Ikshurasadi Dravya Sevana, Vasa, Masha, Godhuma, Krushara, Madhuraphala, Navanna, Shaskuli, Amadugdha, Kadaliphala, Kharjura are the Kapha Prakopaka Ahara.

\section{Viharajyanya :}

Avyayama, Alasya, Ratrijalapana, Adhika Jalapana, Chardi Vegadharana, Virechana Ayoga, Asya Sukha, Ajeerna etc are the causative factors which are responsible for the kapha prakopa.

\section{Vata prakopaka hetu:}

\section{Aharajanya :}

Rukshanna Sevana, Kashaya, Tikta,Katu Dravya Adika Sevana, Mudgha,Sevana, Vishthambi Padartha Sevena ,Tranadhanya, Vishthambhi, Heenabhojana,Shushka Bhojana. 


\section{Viharajyanya:}

Ativyayama, Aptarpana, Langhana, Dhatukshaya, Ratrijagrana, Vegavidharana, Atishoka, Atishita, Atibhaya, Kshobha, Ativyavaya, Atiadhyashana, Abhighata, Bharaharana, Anashana, Vishamashana, Adhyashana, Chinta, Rogajanya, Krushata, Dukha Shayana.

\section{Rakta prakopa hetu:}

Aharajanya:

The factors which are responsible for thevitiation of pitta dosha also vitiate the rakta dosha.

Lavana, Kshara, Amla, Katurasa Ati Sevana, Kulatha, Masha, Kalaya, The Food Stuff Made With More Amount Of Oil, Mulakadi Harita Padartha Sevana, Jalachara Pashu Pakshi Mamsa Sevana, Dadhi, Kanji, Dadhimanda, Sirka, Atimadyapana, Dushita Padartha Sevana.

\section{Viharajyanya:}

1. Drava, Snigdha, or Gurubhojana Paschata Shayana, Krodha, Vamanadi Vega Dharana, Ati Divaswapana, Vikrata Madya Ati Sevana.

2. The symptoms like Kushta, Visarpa, Pidaka, Rakta-Pitta, Asragdhara, Dadru, Charmadala, Switra, Pama, Kothasramandalam are produces due to vitiation of rakta dosha.

3. Kalaja factors are also influences the disease such as vasanta, grishma, mid day, sharat kala, swabhawa.

\section{Purva rupa:}

The purva rupa is one which originates before the onset of the proper disease.

The disease yuvan pidika is mentioned under the heading of kshudra rogas.

The exact purva rupa of the disease is not available in most of the ayurvedic classics, becausewe find the minimal explanation regarding the yuvan pidika which is available under kshudra roga. The meaning of kshudra roga is small of laghu so it would not attain more severity.

For every kshudra roga the involvement of doshas and dushyas are not explained in detail but they have been understood according to their symptoms. Accordingly no purvarupas are mentionedin the disease context. Alpa avyakta lakshanas are referred as purvarupas in general. Thus symptoms like toda, small pidakas, kandu etc can be taken as purvarupa ${ }^{11}$.

\section{RUPA:}

"Pradurabhuta lakshanam punarlingam"(C. S. Chi. 1/16)

When purva rupa sthita lakshanas shows its proper effect or symptoms, it is consider as rupa.

The purvarupa of the disease yuvan pidika is not available in most of the ayurvedic classics but the rupavastha of the disease is explained by all the acharyas.

Vata, pitta, kapha are the responsible factors for almost all the nija vyadhis but the sign and symptoms manifested depend on the predominant dosha.

After the completion of dosha - dushya samurchana and sthansamshraya particular sign and symptoms appear which are known as rupa of the disease. Sometime hidden features of the disease become fully manifested which is known as rupa ${ }^{12}$.

The pidaka resembling the kantaka of salmali tree, which are found on the face of the young people due to deranged condition of kapha, vata, pitta and rakta are called as yuvan pidika ${ }^{13}$. In other context there is a mention on the time of occurrence which is usually in young people during their adolescence or yuvan period. All the acharyas has explained that this disease occurs in yuvavastha.

Detail explanation of the lakshanas of the yuvan pidika has been given by Acharya Vagbhta ${ }^{14}$ and then acharya Sushruta.The eruption packed with the meda, similar to the thorn of shalmali having their site on the face and which is very painful on touch are called as yuvan pidika or mukhadushika. 


\section{Lakshanas according to the acharya vagbhata:}

1. Shalmali kantakakara-The eruption which are found on the face these are conical shape, resembling the kantaka of te shalmali tree and having its base on the face called as yuvan pidika. It is also opined that there is similarity between shape of the thorn and eruption, but some believe that the pain experienced is same as pricking of the shalmali kanta. (Hansaraj nidana kshudra roga, 22)

2. Pidika- the lesions which appears in the form of eruption is known as pidika.

3. Saruja- the eruptions are painful, the pain may be severe or mild.

4. Ghana- the pidaka which is Ghana on touch is due to vitiated kapha ${ }^{15}$.

5. Yuna Mukhe- this word shows the site of origin of pidika and time of occurrence of the disease. Disease occurs in young age and affects the mukha or face. (A. H. U. 31/5 keraliya tika)

6. The disease which occur in the young age in naturally is called as yuvan pidika ${ }^{16}$.

7. Symptoms,involvement of doshas according to different acharyas are mentioned in the above table.

\section{Samprapti Of Yuvan Pidika -}

Samprapti of the vyadhi is important for the understanding of the specific features of the vyadhi as well as essential for the line of management. Generally in the samprapti of the disease, the component to be essentially considered are doshas, dushaya, srotas, agni, ama, sthanasamshraya of the doshas at the point of khavaigunya producing a disease.

According to Acharya Shushruta and Vagabhata, the vitiated kapha, vata, rakta and medas causes the development of pidakas on the mukha which resembles the Shalmalikantaka. These causative factors and symptoms have been accepted by other Acharyas like Vangasena ${ }^{17}$, Madhavakara ${ }^{18}$, Bhavaprakasha ${ }^{19}$, but in Sharangadhara samhita Vaktra snigdhata and pidaka have been mentioned which are produced dueto shukradhatu mala ${ }^{20}$. The samprapti of the disease is formulated as follows.

\section{Kapha, vata, rakta prakopaka nidana}

Raktadi and Shukra vaishamya

Excess of Shukradhatu mala

Vaktra snigdhata

SAMPRAPTI GHATAKA :

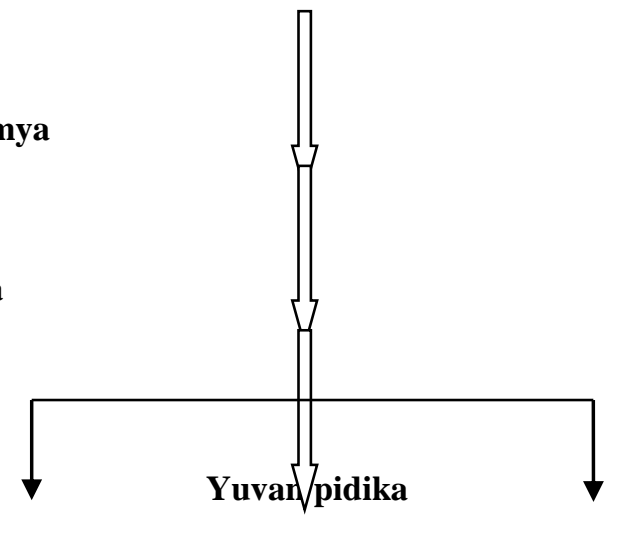

Dosha $\quad$ - kapha - vata

Dushya - Rasa, Rakta, Meda

Mala $\quad-$ Twakasneha

Srotas $\quad$-Rasavaha, Rakta

Shrotodushti - Sanga

Agni - Jatharagni mandya

Adhisthana - Twaka

Samutthana - Ama pakwashaya

Rog marga - Bahya

Apart from multiple nidanas like Aharaja, viharaja, manshika and kalaja bhavaprakasha has revealed that the swabhava indicates the yuvavastha of the person, and the shukra dhatu is produced in excess quantity, which is a natural process. All the causative factor have their effects on dosha, dushyas, agni and srotas. 
Kapha, vata and pitta vitiates due to their independent factors that inturn vitiate rakta, meda and twak.due to production of ama there is agnimandhya. This vitiated agni influences dosha prakopa and dushya dourbalyata. Due to viprakristra nidana khavaigunya takes place in raktavaha srotasa and twaka of face, neck and back.

Sthanasamshrya of the doshas takes place due to dourbalya of twaka, rakta and meda. Due to the nidana sevana the disease process leads to srotodushti, where sanga occurs by the doshas.

Here in this disease sthanasamshrya of the doshas takes place due to dourbalya of twaka, rakta and meda. The disease process leads to srotodushti, due to continuation of nidanasevana and sanga occurs by the doshas. Vitiated kapha and medas get dried up to vata dosha and this stage is considered to be a dosha-dushaya samurchana. In this stage the purvaroopa will be manifested. Symptoms like vaktrasnigdhata, medogarbhita pidaka canbe taken as purvarupas in this disease.

In rupavashta stage the clinical features depend on the doshas and dushyas involved. Rupas like shalmali kantakakara saruja, Ghana, medogarbhita pidika will be seen. Among these sanjata is due to vata dominance, Ghana, medhogarbhita are due to kapha predominance and brownish colored lesions and paka shows rakta dusti.

\section{Types Of Yuvan Pidika-}

There is no description of yuvan pidika types found in the ayurvedic classics but on the basis of predominant dosha involvement and the symptoms the disease can be classified.

The sign and symptoms of the eruptions like- which are very full, ruksha on touch, Krishna varna can be taken as vataja type.

The eruption which are predominantly has kandu, aruna varna, kathina mild pain can be taken as kaphaja type.

The eruption which are black or reddish in colour, with radish discharge then it is considered as raktaja yuvan pidika.

Symptoms that appear after the combination of two doshas are considered to be dwandwaja.

\section{Upadravas:}

If the disease is not treated in initial stage then it enters in to a complicated stage which ferther leads to deterioration of the disease. The term mukhadushika itself suggests the adverse effect of the treatment. When it is not treated in early stage then it produces the complications like vaivarnya, discoloration, scar, pigmentation etc.

\section{Chikitsa:}

"Tatha chaturnam bhishagadinam shastanam dhatvaikrute|Pravrattihi dhatusamyartha chikitsetyabhidiyate||" (C. S. Su. 5)

Acharya charaka has explain removing the causative factors of the disease may not always result in the total removal of the disease as such because, the effect of the disease may still continue to be functioning. "Hence in this view, chikitsa aims not only the at the radical removal of the causative factors of the disease, but also the restoration of the dosha, dhatu and mala samyata or equilibrium i.e. homeostasis.

Mainly two type of chikitsa has been mentioned in our classics i.e. shaman and shodhana. With the samana line of treatment the disease are going to get cured but there will be every possibility of reoccurrence. Shodhana line of treatment cures the disease from its root and cures permanently. yuvan pidika treatment is explained in different classics under these two headings, so raktamokshana type of treatment comes under the shodhana chikitsa hence considered to be best. The disease yuvan pidika comes under the kshudra roga hence kshudra roga samanya sutra can be taken as yuvan pidika samanya chikitsa sutra.

Kalyanakaraka, in the context of treatment of different kinds of kshudra roga explained,thecausative factor, symptoms, predominant doshik involvement, and treatment like pradeha, lepana,rakta mokshana, upanaha etc for each and every kshudra roga separately ${ }^{21}$. 


\section{Shodhana karma in Yuvanpidika-}

According to acharya sushruta vamana karma is considered as the best line of treatment in Yuvanapidaka. Even other classics like AshtangaSangraha, Ashtanga Hridaya, Chakradata,Gadanigraha, Bhavaprakasha, Bhaishjya ratnavali, Rasakamadhenu considered Vamana karma as the best line of treatment in Yuvanapidaka ${ }^{22,23,24,25,26,27}$.

The involvement of the dosha in the yuvan pidika is Kapha, vata and rakta. To get rid from these vitiated doshas, raktamokshana is one of the best line of treatment explained in our classics. As per different classics, in yuvan pidika siravyadha must be performed ${ }^{28,29}$.

\section{Lepadi prayoga in Yuvanpidika-}

According to acharya sushruta the lepa plays a very important role in curing the disease yuvan pidika. Acharya mentions different type of lepas prepared from Vacha, Lodhra, Saindhava, Sarshapa And Dhanyaka, which are beneficial in Acne as well as in improving the complexion.

\section{According to Astanha Hridya:}

1. Application of lepa prepared with the combination of Dhanyaka, Vacha and Lodhra in yuvan pidika ${ }^{30}$.

2. Yava pishta, Rala, lodhra, Khasha, Raktachandana churna, Madhu, Ghrita and Guda which are taken in equal quantity in a vessel and add 4 parts of gomutra and make a paka until it attains a semisolid state. Later take it out from the agni and cool it.this prepration can be applied over the acne lesions.

3. Application of lepa prepared with the combination of saindhava, Vacha, Lodhra, Sidhartaka, Adhaki ${ }^{31}$.

In chakradatta following kinds of lepa preparations are indicated -

1. Application of the paste prepared from Lodhra, Vacha, Dhanyaka, Gorochana with marich over the Acne lesion.

2. Paste prepared from sweta sarshapa, Vacha, Lodhra and saindhava lavana.

3. Lepa prepared with matulunga moola, ghrita, manashila and gorasa.

4. Lodhra, vacha, dhanya lepa, gorochana, maricha lepa, sweta sarshapa, vacha, lodhra, saindhava lepa, vata pakwa patra, malati, raktachandana, lodhra, kushta, pitta chandana; with these combinations prepare a lepa and apply it ${ }^{32}$.

1. Acharya Yogaratnakara also contributes some of the lepa preparations for the disease acne- jayaphala, chandana, maricha powder.

2. Lepa prepared from sweta sarsapa vacha, lodhra and saindhava lavana.

3. Application of Gorochana and maricha.

4. Lepa with Shalmali kantaka and kshira.

5. Lepa prepration from vata pakwa patra, malati, rakta chandana, kushtha, kaliyaka and lodhra.

6. Lepa preparation with matulunga root, ghrita, manashila and gorasa ${ }^{33}$.

7. In Arka Prakasha one more preparation is available i.e. Shalmali Kantaka paste is prepared with milk and the arka is to be extracted then apply the same over the acne lesion.

8. Taila and ghrita prayoga in yuvan pidika -

The medicated taila and ghrita can be used internally as well as externally in the disease yuvan pidika.

1. Haridra taila ${ }^{34}$

2. Manjista taila ${ }^{35}$

3. Kumkumadya taila ${ }^{36}$

4. Dwaharidradi taila ${ }^{37}$

5. Sahachara ghrita ${ }^{38}$

6. Kumkumadya ghrita ${ }^{39}$

7. One more special treatment mentioned by the Vangasena is tila taila pratimarsha nasya which is very beneficial in $\operatorname{acne}^{40}$.

8. Rasendrasara Sangrahakara gives the special preparation called Parada Bhasma pragyoga in yuvan pidika.

\section{Conclusion:-}

Yuvan pidika is a one of the ksudra rogas, pidika resembling thorn of shalmali tree with the predominant of kapha, vata and rakta occurring on the face in yuvavastha is known as yuvan pidika. It contains meda in its core and associated with pain. 


\section{Bibliography:-}

1. Raja Radhakanta Dev virachita shabdakalpadruma, tritiya khanda, Nag publisher, jawaha Nagar, Delhi, reprint 987, Pp-792, P104.

2. Raja Radhakanta Dev virachita shabdakalpadruma, tritiya khanda, Nag publisher, jawaha Nagar, Delhi, reprint 987, Pp-792, P 104.

3. Raja Radhakanta Dev virachita shabdakalpadruma, tritiya khanda, Nag publisher, jawaha Nagar, Delhi, reprint 987, Pp-792, P-104.

4. Amarmishra, amarkosha, printed by Chaukhambha Sanskrit samsthan, Varansi, reprint 2006, Pp668, P77.

5. Madhavakara, Madhavanidana, Varansi, chaukhamba Sanskrit sansthan,13th edition, 200,Pp508, p208.

6. Sushruta, sushruta samhita, Varanasi, chaukhambha subharati, $7^{\text {th }}$ edition, 2008, Pp-824, P-323.

7. Sushruta, sushruta samhita, Varanasi, chaukhambha subharati, $7^{\text {th }}$ edition, $2008, \mathrm{Pp}-824, \mathrm{P}-323$.

8. Raja Radhakant dev virachita shabdokalpadrum, tritiya khanda, Delhi, nagpublishers, jawahar nagar, reprint 1987, Pp-792, P-104.

9. Bhavamishra, Bhavapraksha, Varansi, Chaukhamba orientalia, $7^{\text {nd }}$ edition, 1998, Pp-824, P-124.

10. Sharangadhara, sharangadhar samhita, varanasi, Chaukhamba oriyantalia,Pp-578, P-43.

11. Madhavakara, madhavanidana, varanasi, Chaukhamba Sanskrit sansthan, $13^{\text {th }}$ edition, $2002, \mathrm{pp}-508, \mathrm{P} 192$.

12. Vagbhata, astanga hridaya,varanasi, Chaukhamba orientalia, $9^{\text {th }}$ edition, $2005, \mathrm{Pp}-956, \mathrm{P}-441$.

13. Sushruta, sushruta samhita, Varanasi, chaukhambha subharati, $7^{\text {th }}$ edition, $2008, \mathrm{Pp}-824, \mathrm{P}-323$

14. Vagbhata, astanga hridaya,varanasi, Chaukhamba orientalia, $9^{\text {th }}$ edition, 2005 , Pp-956, P-888.

15. Kalynakaraka, ugaditacharaya, sheth govindaji raoji, doshi, sakharam nemchanda grantha mala,1940, PP-748, P-302.

16. Bhavamishra, Bhavapraksha, Varansi, Chaukhamba orientalia, $7^{\text {nd }}$ edition, 1998, Pp-824, P-124.

17. Vangasena, vangasena samhita, Mumbai, khemaraj krishnaraja prakashana, Pp-1064, P-682-683.

18. Madhavakara, madhavanidana, varanasi, Chaukhamba Sanskrit sansthan, $13^{\text {th }}$ edition, 2002, pp-508, P-192.

19. Bhavamishra, Bhavapraksha, Varansi, Chaukhamba orientalia, $7^{\text {nd }}$ edition, 1998, Pp-824, P- 124.

20. Sharangadhara, sharangadhar samhita, varanasi, Chaukhamba oriyantalia,Pp-578, P-43.

21. Kalynakaraka, ugaditacharaya, sheth govindaji raoji, doshi, sakharam nemchanda grantha mala,1940, PP-748, P-302.

22. Sushruta, sushruta samhita, Varanasi, chaukhambha subharati, $7^{\text {th }}$ edition, $2008, \mathrm{Pp}-824, \mathrm{P}-323$.

23. Vagbhata, astanga hridaya,varanasi, Chaukhamba orientalia, $9^{\text {th }}$ edition, $2005, \mathrm{Pp}-956, \mathrm{P}-890$.

24. Vagbhata, astanga sangraha,delhi, shri satguru publication, $2^{\text {nd }}$ edition, $1990, \mathrm{Pp}-965, \mathrm{P}-819$.

25. Vagbhata, astanga sangraha,delhi, shri satguru publication, $2^{\text {nd }}$ edition, $1990, \mathrm{Pp}-965, \mathrm{P}-81$.

26. Rasakamdhenu, vaidhya santosh kumar Sharma, varanasi, Chaukhamba orientalia, $2 \mathrm{nr}$ edition, Pp-476, P-230.

27. Govindadas, bhaishajya ratnavali, varansi chaukhamba samskrit samsthan, 2000, Pp-1196, P-934-935.

28. Vagbhata, astanga sangraha,delhi, shri satguru publication, $2^{\text {nd }}$ edition, 1990 , Pp-965, P-819.

29. Vagbhata, astanga sangraha,delhi, shri satguru publication, $2^{\text {nd }}$ edition, 1990, Pp-965, P- 819.

30. Vahbhata, astanga hridaya,varanasi, Chaukhamba orientalia, $9^{\text {th }}$ edition, 2005, Pp-956, P- 890.

31. Vagbhata, astanga hridaya,varanasi, Chaukhamba orientalia, $9^{\text {th }}$ edition, 2005, Pp-956, P-890.

32. Bhavamishra, Bhavapraksha, Varansi, Chaukhamba orientalia, $7^{\text {nd }}$ edition, $1998, \mathrm{Pp}-824, \mathrm{P}-124$.

33. Yogaratnakara, Lakshmipati shastri, varansi, chaukhambha publication $1^{\text {st }}$ edition, reprint 2008 , Pp-504, P-275.

34. Vangasena, vangasena samhita, Mumbai, khemaraj krishnaraja prakashana, Pp-1064, P- 684.

35. Vangasena, vangasena samhita, Mumbai, khemaraj krishnaraja prakashana, Pp-1064, P-684.

36. Vangasena, vangasena samhita, Mumbai, khemaraj krishnaraja prakashana, Pp-1064, P-685.

37. Chakradatta, Sharma P V, $1^{\text {st }}$ edition, 2007, chaukhambha orientalia, Pp-731, P439.

38. Bhavamishra, Bhavapraksha, Varansi, Chaukhamba orientalia, $7^{\text {nd }}$ edition, $1998, \mathrm{Pp}-824, \mathrm{P}-124$

39. Bhavamishra, Bhavapraksha, Varansi, Chaukhamba orientalia, $7^{\text {nd }}$ edition, $1998, \mathrm{Pp}-824, \mathrm{P}-124$.

40. Vangasena, vangasena samhita, Mumbai, khemaraj krishnaraja prakashana, Pp-1064, P- 683. 